\title{
CONFLICT AND INTEGRATION IN THE SALAFI-WAHABI PURIFICATION MOVEMENT IN SOUTH KALIMANTAN
}

\author{
Muhammad Zainal Abidin \\ UIN Antasari Banjarmasin \\ J1. A. Yani No.KM.4, Kota Banjarmasin, Kalimantan Selatan, Indonesia \\ E-mail: mzabidin@uin-antasari.ac.id \\ Yulia Hafizah \\ UIN Antasari Banjarmasin \\ Jl. A. Yani No.KM.4, Kota Banjarmasin, Kalimantan Selatan, Indonesia \\ E-mail: yuliahafizah79@gmail.com
}

\begin{abstract}
This article intends to discuss the development of the Salafi-Wahabi movement in South Kalimantan in relation to conflict and integration. In South Kalimantan, the development of the Salafi-Wahabi movement was quite fast. Although less than two decades, this group's preaching has covered almost all regions in this province. The development of this group in recent years has become a topic of discussion among people in South Kalimantan, in both ways: pro and contra. This article employs a qualitative method that contains the study of literature and fieldwork. Fieldwork conducted in Banjar, South Kalimantan, to gather data related to the development of the Salafi-Wahabi movement and its implications to the changes community's social order related to conflict and integration. The research shows that there are many issues of the Islamic purification movement that caused a strong response from the community that potentially prone to conflict. For example, are its teaching on Tawheed (monotheism) and accusation of many practices as bid'ah (heresy), which targeted respected local figures or groups like Guru Sekumpul in traditional circles. It becomes the main factor of the negative view of the Salaf-Wahabi group. However, there are some efforts made by Salafi-Wahabi to integrate their activities into the Banjar community.
\end{abstract}

Keywords:

Conflict; Integration; Islamic Purification; Salafi-Wahabi.

\section{Abstrak}

Artikel ini bermaksud membahas tentang perkembangan gerakan pemurnian salafi-wahabi di Kalimantan Selatan dalam kaitannya dengan konflik dan integrasi. Di Kalimantan Selatan perkembangan gerakan Salafi-Wahabi cukup pesat. Meski usianya belum sampai dua dasawarsa, tetapi dakwah kelompok ini telah meliputi hampir semua kawasan di propinsi ini. Perkembangan kelompok ini dalam beberapa tahun terakhir cukup menjadi perbincangan di kalangan masyarakat umum di Kalimantan Selatan, baik pro ataupun kontra. Artikel ini menggunakan metode kualitatif dengan data dikumpulkan berdasarkan kajian lapangan. Penelitian dilakukan di kota Banjarmasin, Martapura, dan Barabai Kalimantan Selatan. Penelitian ini menunjukkan bahwa ada beberapa isu yang rentan menimbulkan konflik, yakni secara material berkaitan dengan ajaran salafi-wahabi berkenaan dengan konsep tauhid dan bid'ah, yang menyasar kepada figur-figur yang dihormati di kalangan tradisional. Meski demikian, ada upaya yang dilakukan kalangan salafiwahabi sebagai bentuk upaya mereka melakukan integrasi kepada masyarakat Banjar. Di antara strategi tersebut adalah dengan membangun relasi yang baik dengan masyarakat sekitarnya, tidak terlalu menunjukkan keberbedaan dalam pelaksanaan ajaran Salafinya, aktif dalam memberikan bantuan sosial sambil tetap mengajak untuk kembali ke ajaran utama dari Alquran.

Kata Kunci:

Integrasi; Konflik; Pemurnian Islam; Salafi-Wahabi.

DOI: $10.15575 /$ jw.v4i2.6194

Received: October 20, 2019 ; Accepted: December 30, 2019 ; Published: December 31, 2019 


\section{A. INTRODUCTION}

The Islamic purification movement in various phases of history has caused multiple reactions in the community, specifically those who are considered to be 'deviant.' ${ }^{1}$ In Indonesian, many studies about Islamic purification have been conducted by several scholars like Hasan, ${ }^{2}$ Wahid, ${ }^{3}$ Qadim, ${ }^{4}$ Faizah, ${ }^{5}$ Tarwiyah, ${ }^{6}$ and Fuad. ${ }^{7}$ The Islamic purification movement as a thesis has caused the response to that purification, which is called antithesis. Furthermore, the debate between the Islamic purification ${ }^{8}$ movement and the response to the movement gives rise to integration, as a synthesis effort to minimize the conflict. ${ }^{9}$

In South Kalimantan, the idea of purifying Islam went through three phases of development. In the $18^{\text {th }}$ century, there was a great cleric figure, Sheikh Muhammad Arsyad al Banjari. In his book, Tuhfah al Raghibin, he said that there are three main aspects of Islamic purifications: the wujudiyah sect, the manyanggar banua and mambuang pasilih tradition, and becoming friends with the Jinn to gain muwakkal knowledge. ${ }^{10}$ This purification movement was the antithesis of the practice of some Banjar people at that time, with their Islamic purification orientation related to monotheistic aspects. ${ }^{11}$

In the next phase, the idea of purifying Islamic teaching, as carried out by Sheikh Muhammad Arsyad Al Banjari, is no longer sufficient. At the beginning of the $20^{\text {th }}$ century, its Islamic purification movement was greatly influenced by Muhammadiyah, the Islamic purification movement born in Yogyakarta. The purification activities of Muhammadiyah is first appeared in South Kalimantan, particularly in Alabio. ${ }^{12}$ The problem that is quite prominent and caused internal conflicts with the traditionalists at that time were: talaffudz bi al-niyah or ushalli, talqin, asyraqal, hilah, and maarwah (aruh downland), maniga hari (three-days ritual), manujuh hari (seven-days ritual), manyalawi (twenty five-days ritual), mampat puluh hari (forty days-ritual), manyaratus (one hundred days-ritual) and mahaul (one year-days ritual). ${ }^{13}$

At the beginning of the $21^{\text {st }}$ century, these controversial issues that happen between kaum tuha (the traditionalist) and kaum muda (the

\footnotetext{
${ }^{1}$ Mutohharun Jinan, "Dilema Gerakan Pemurnian Islam," Ishraqi 4, no. 1 (2008): 57-72.

${ }^{2}$ N. Hasan, "The Salafi Movement in Indonesia: Transnational Dynamics and Local Development," Comparative Studies of South Asia, Africa and the Middle East 27, no. 1 (January 1, 2007): 83-94, https://doi.org/10.1215/1089201x-2006-045.

${ }^{3}$ Din Wahid, "Nurturing Salafi Manhaj A Study of Salafi Pesantrens in Contemporary Indonesia," Wacana 15, no. 2 (2015): 367-76.

${ }^{4}$ Husnul Qodim, "Dinamika Salafisme Di Indonesia: Akar-Akar Intelektualitas Dan Orientasi Ideologis Yang Beragam," Tashwirul Afkar: Jurnal Refleksi Pemikiran Keagamaan Dan Kebudayaan, no. 21 (2007): 46-74.

${ }^{5}$ Faizah Faizah, "Pergulatan Teologi Salafi Dalam Mainstream Keberagamaan Masyarakat Sasak," Ulumuna 16, no. 2 (November 7, 2017): 375-402, https://doi.org/10.20414/ujis.v16i2.183.

${ }^{6}$ Siti Tarwiyah, "Perkembangan Dan Tantangan Sosial Kehidupan Perempuan Salafi Di Kalimantan Selatan," Jurnal Lektur Keagamaan 15, no. 2 (December 30, 2017): 470, https://doi.org/10.31291/jlk.v15i2.533.

${ }^{7}$ A Jauhar Fuad, "Infiltrasi Salafi Wahabi Pada Buku Teks Di Madrasah Dan Respons Warga Nahdliyin," Marâji: Jurnal Ilmu Keislaman 1, no. 2 (2015): 361-92.
}

${ }^{8}$ The word purification means the effort to pure something. In this context, Islamic purification means that in the course of historical Islam, Islam as a religious teaching is seen no longer pure, it's influenced by other teachings of local culture, so it must be purified in order to be an authentic Islam as it came for the first time and practiced by the prophet in his companions.

${ }^{9}$ Abadir M Ibrahim, "Localizing Salafism: Religious Change among Oromo Muslims in Bale, Ethiopia," African Studies Quarterly 16, no. 2 (2016): 127-28.

${ }^{10} \mathrm{H}$.M. Asywadie Syukur, Pemikiran-Pemikiran Syeh Muhammad Arsyad Al Banjari Dalam Bidang Tauhid Dan Tasawuf (Banjarmasin: COMDES, 2009), 9.

${ }^{11}$ Anita Arianti, "Gerakan Pemurnian Islam Syekh Muhammad Arsyad Al-Banjari Di Kalimantan Selatan," Al-Fikr 14, no. 3 (2017): 377-90.

${ }^{12}$ Administrator, "Sejarah Awal Muhammadiyah Di Kalimantan Selatan," PW Muhammadiyah Kalsel, accessed October 13, 2019, http://kalsel.muhammadiyah.or.id/content-3-sdetsejarah.html.

${ }^{13}$ Rahmadi Rahmadi, "Pembaharuan Islam Di Kalimantan Selatan Awal Abad Ke-20," Al-Banjari: Jurnal Ilmiah Ilmu-Ilmu Keislaman 13, no. 1 (May 12, 2014), https://doi.org/10.18592/al-banjari.v13i1.390. 
modernist $)^{14}$ reemerged with the coming of a new model of the puritan group, the SalafiWahabi. The emergence of the Salafi-Wahabi purification movement in South Kalimantan province is related to the religious phenomena that are prevalent in the midst of society. ${ }^{15}$ Several religious activities in South Kalimantan mingled with local culture as a form of accommodation of local tradition. Many purification movements try to show that there are no evidence texts in Islam to represent their religious traditions. Many of these traditions are categorized as heresy in religion, superstition, and khurafat, which, according to them, are not in line with the prophet tradition and the Qur'an. ${ }^{16}$

In general, there are two main issues of the idea of Islamic purification teachings carried out by the Salafi-Wahabi: shirk (syirk) and heresy (bid'ah). ${ }^{17}$ Shirk referred to the 'deviation' of the beliefs of Banjar people. Heresy is related to the practice of worship, which is not following the practice of the Muslim majority. These two aspects, shirk and heresy, are sensitive issues and potentially tend to cause conflict.

Moreover, it will become a latent danger which, if not appropriately managed, can lead to lousy potential in maintaining the diversity in this country. ${ }^{18}$

This paper aims to provide a portrait of the conflict that arose from the Islamic purification movement in South Kalimantan and the integration strategy undertaken by the WahabiSalafi to be accepted by the Banjar community.

This article is the result of field research conducted in South Kalimantan, particularly in Martapura and Barabai. The data obtained

\footnotetext{
${ }^{14}$ Deliar Noer, Gerakan Moderen Islam Di Indonesia 1900-1942 (Jakarta: LP3ES, 1996), 339.

${ }^{15}$ Takdir Ali Syahbana, "Fenomena Salafi Di Kalimantan Selatan," Jurnal Ilmiah Ilmu Ushuluddin 14, no. 1 (2016): 67-82.

${ }^{16}$ Simply shirk means associating partners with God while bid'ah means worshiping outside of His statutes. See Agus Moh. Najib, "Gerakan Wahabi: Ajaran Dan Metode Penyebaran," in Gerakan Wahabi Di Indonesia
}

through observations and interviews. The choice of location is based on the presence of Salafi and the possible potential conflict given in these two regions. In Martapura, there was a prominent religious figure, namely $\mathrm{K}$. $\mathrm{H}$. Muhammad Zaini bin Abdul Ghani (Guru Ijai or known as Guru Sekumpul), who passed away in 2005. In Barabai, there is also a living religious figure, K.H. Muhammad Bachiet (Guru Bachiet). Guru Sekumpul was the most popular religious leader, and he often being criticized by the Salafists.

\section{B. RESULT AND DISCUSSION}

There are three sources of conflict caused by the presence of the Salafi-Wahabi groups in South Kalimantan, namely: First, Salafi criticism to the respected figure of traditionalist Islamic circles; second, the strong doctrine of Salafi teachings around tawheed and sunnah which has implications for the emergence of the concept of shirk and heresy; third, reduced cohesiveness of emotional ties among communities as a result of differences in many aspects such as the may to dress the relationships between men and women, neglect of the tradition of thanksgiving or baaruh which is generally a unifying media in South Kalimantan's society. The following sections explain in detail the conflict emerged.

\section{Conflict because of criticism of Guru Sekumpul}

The first case is the conflict between Salafi and the followers of Guru Sekumpul. The dispute began when the followers of Guru Sekumpul celebrate his hundred-days commemoration (haul) after his death. The Salafi accused this celebration as heresy and

(Dialog Dan Kritik, ed. Yudian Wahyudi (Yogyakarta: Bina Harfa, 2009).

${ }^{17}$ Din Wahid, "Challenging Religious Authority: The Emergence of Salafi Ustadhs in Indonesia," Journal of Indonesian Islam 6, no. 2 (December 1, 2012): 245-64, https://doi.org/10.15642/JIIS.2012.6.2.245-264.

${ }^{18}$ Mujiburrahman, "Islamic Theological Texts and Contexts in Banjarese Society: An Overview of the Existing Studies," Southeast Asian Studies 3, no. 3 (2014): 611-641. 
khurafat that no base in Islam. The Salafi thought on this matter is published in the Salafi social media and viral among the community that sparked the conflict.

In 2013, a quite famous Salafi cleric, UF, who often invited to preach in Banjarmasin uploaded an old video of Guru Sekumpul, who recounted his spiritual experiences that he met the prophet in His grave during the pilgrimage. UF conveyed some points in his writing related to the definition of a companion (sahabat) that, according to him, becomes 'problematic' when there is a claim of someone meet the prophet Muhammad in person, not in dreaming. According to UF, this claim is exaggerated and unacceptable and categorized as khurafat. The claim made by Guru Sekumpul, originally appeared in Banjar language. One of Salafi ustadz, UAZ, translated it into Indonesian and became a mockery among Salafi adherents. In this translation mentioned that Guru Sekumpul met the Prophet directly - that the Prophet raised from his graveyard, kiss his knees, and accompanied Guru Sekumpul to his bed. Besides, according to this translation, all of the Prophet's wives present at that time.

In Kalimantan, the defense of Guru Sekumpul's lectures from his pupils was quite significant. One of them was a famous teacher, KH. M. Zhofaruddin (Guru Udin) from Samarinda, who explained about the video recording Guru Sekumpul preaching, which was misunderstood by many people, specifically related to the content that the Prophet kissed his knees. According to him, it is not the Prophet who kissed the knees of Guru Sekumpul but otherwise.

Besides, there was a viral lecture in 2018 from one of Salafi preacher, USB, who criticized the tradition of a cult in society to a particular figure more than the appreciation to the Prophet. He addressed the worship of many people to Guru Ijai from Martapura in one of his preachings. This viral preaching soon received a robust response from the pupils of

\footnotetext{
${ }^{19}$ This view is typical of the traditional views of rural communities, while the views of urbanites undergo rapid change. See Muhammad Zainal Abidin, "Ulama in
}

Guru Sekumpul. One of his pupils is Habib Ahmad Hanafi Hariri Bahasyim, through the social media calling on all Muslims and the followersof Abah Guru Sekumpul all over Indonesia and specifically in Kalimantan to gather on July 12, 2018, at Masjid Raya Sabilal Muhtadin. One of the plan is to protest and submit a petition against all forms of discrimination against Aswaja (Ahlussunnah wa al-Jamaah) figure.

The figure of Guru Sekumpul was a sacred person and especially for the Aswaja's circles. Any forms of criticism will raise protests. ${ }^{19}$ In South Kalimantan itself, it is considered an insult to the Master and also his students.

In general, Salafis' criticism about Guru Sekumpul caused a negative response from the traditional community in South Kalimantan. Most of the people were not happy with the existence of Salafis and their preaching activities in South Kalimantan.

\section{Conflict as a result of Understanding Religious Doctrines: Tawheed and Sunnah}

Two Salafi doctrines, tawheed, and sunnah, has implications for the emergence of shirk and bid'ah (heresy) concept in viewing amaliyah among traditionalists. The issue of tawheed and sunnah is fundamental to Salafi propaganda. These aspects are specific characteristics of this group. These issues also had a strong dimension to the spirit of Islamic purification. The concept of Tawheed opposed the idea of shirk, and the term bid'ah is an antithesis of the the sunnah.

Salafi has its typical characteristics in interpretation tawheed concept. There are three categories of tawheed, namely: tawheed rububiyyah, tawheed uluhiyyah and tawheed asma and sifat. Tawheed rububiyyah is an acknowledgment that Allah is the Rabb of all things and the king of all things, the creator and the keeper of all things, who has the right to govern everything and there is no partner in His

Indonesian Urban Society: A View of Their Role and Position in the Change of Age," Jurnal THEOLOGIA 28, no. 2 (2018): 235. 
power. ${ }^{20}$ Ttawheed rububiyyah affirms Allah in every action because $\mathrm{He}$ is Allah, the Creator, the Provider of wealth, $\mathrm{He}$ is the one who governs all His creations. He also takes care of them with what He bestows in the form of pleasure and faith in all of Allah's actions. ${ }^{21}$

Second, tawheed uluhiyah. It is acknowledgment about God with all types of physical and spiritual worship, both words and deeds, and reject all forms of worship others than Allah SWT. ${ }^{22}$ Consequently, it is not permissible to pray and sacrifice except to Allah SWT. There is no tawwaf except in His house, may not ask for help, and may not put their trust but to Rabb. ${ }^{23}$ Witnesses that there is no God but Allah and testify that Muhammad is the messenger of God demands on the conditions that the deeds of worship are to be accepted. In other words, the worship only for God alone, and ittiba' purification to follow the Prophet in worshiping Allah. Because the Prophet leads us to worship Allah, while others not. $^{24}$

This kind of Tawheed, according to many Salafis, is essential to be guarded and practiced. Unbelievers deny it and became a source of contention and conflict between previous peoples and the apostles, from the Prophet Noah until the Prophet Muhammad. ${ }^{25}$ The essence of tawheed uluhiyah in worshiping God contains two aspects: first, to pray only to God alone and accept God's divinity; Second, to follow the Prophet in prescription on how to worship Allah. This worship must be solely intended as obedience and a statement of gratitude to God. ${ }^{26}$

Among the crucial aspects of the Salafi $d a$ 'wah include: 1) The worship directed only to Allah and those who worship other than Allah is called polytheists and may be killed;2) many Muslims are no longer follow the pure tawheed because they ask for help to other than Allah. They are considered as polytheists; 3) Giving title and homage to the prophet or a guardian angel, especially in the prayer is regarded as an idolatrous act e.g., inserting the word Sayyidina, habibuna, or syafi'una in prayer. 4) Acquiring and establishing knowledge that is not based on the Qur'an and Sunnah is kufr. 5) Interpreting the Qur'an using takwil is kufr. 6) The ijtihad is always open and must be carried out by capable people. Thus, blind taqlid to the ulama considered a cult that leads to the shirk. ${ }^{27}$

Third, the tawheed asma (names) wa shifat (nature) of Allah, namely believing in all the attributes described to Allah. These attributions are called asmâul husna and ash shifât al ulâ. ${ }^{28}$ With this tawheed, we believe in each of the characteristics and names by which Allah attributes and names Himself. Include in His names are His Greatness and the Quality of each name. ${ }^{29}$

Faith in God's nature means that people should avoid ta'wil (interpretation), tahrif (deviation), takyif (visuals, depictions), ta'thil (cancellation, disclaimer), tamstil (similarity), tafwidh (delivery, such as which is widely understood by many people) to religious doctrins. For example about the nature of al istiwa (residing above), a nuzul (descending), al yad (hand), al maji ' (arrival), and other attributes, then all of these terms must be accepted without interpretation beyond what is written in Nash (the text).

\footnotetext{
${ }^{25}$ Syaikh Muhammad Bin Jamil Zainu, Jalan Golongan Yang Selamat, trans. Ainul Haris Umar Arifin (Jakarta: Darul Haq, 2016), 20.

${ }^{26}$ Najib, "Gerakan Wahabi: Ajaran Dan Metode Penyebaran," 5-6.

${ }^{27}$ Najib, 7-8.

${ }^{28}$ Hakami, Akidah Golongan Selamat, 61. Salafiyyah, 47.
${ }^{29}$ Ramadhani, 6 Landasan Utama Dakwah

\footnotetext{
Pustaka Imam Syafii, 2015), 39.

${ }^{22}$ Hakami, Akidah Golongan Selamat, 47.

${ }^{23}$ Ramadhani, 6 Landasan Utama Dakwah Salafiyyah, 41.

${ }^{24}$ Ramadhani, 6 Landasan Utama Dakwah

${ }^{20}$ Syaikh Hafizh bin Ahmad al Hakami, Akidah Golongan Selamat, trans. Amin Ulwi (Jakarta: Pustaka mam Bonjol, 2015), 55.

Salafiyyah, 94.
} 
Ibn Abdul Wahhab adopted many of Ibn Taymiyah's ideas, especially in the field of Aqeedah, and even tended to be fanatical and tried to actualize them at the time. The implementation of this matter then gave birth to a view that distinguishes it from Ibn Taymiyah (Salafiyah). First, Wahhabis consider not only the issue of worship that must be under the textual rules in the Qur'an and Sunnah but also the customs of society. The implication is that the meaning of heresy is broad, all matters not regulated in the Qur'an and Sunnah are considered acts of worship, including dhikr in a congregation, drawing people, drinking coffee, and wearing a ring for men. The perpetrators are then categorized as infidels or polytheists. This narrow scripturalist view prevents Wahhabi from giving space to the development of local culture in Islam. Second, they disseminate their teachings not only with persuasion but also with swords and violence on the name of fighting heresy. Heresy for them is an evil deed that must be fought, as stated in the Qur'an to fight evil. ${ }^{30}$

The Salafi concept of heresy also emerge when discussing any acts that not in accordance with the Sunnah, which they interpreted literally. ${ }^{31}$

Salafi defined heresy as follows: 1) any practices that are contrary to the Qur'an and Sunnah in the form of words, deeds, and beliefs; 2) any practices that are believed to be a form of taqarrub to Allah and forbidden by the Prophet; 3) Any practices that no based in religious texts and when there are no texts related to that act; 4) any forms of worship that mimic the customs of unbelievers; 5) any practices recommended by one of the ulemas but there is no proof of the argument; 6) any methods of worship taken from the hadith da'eef (weak chain of transmission); 7) Excessive in practicing religion; 8) any practices that should be performed but restricted by humans in terms of place, time or procedure. $^{32}$

Salafis have different views on how to categorize heresy. Heresy, according to Ahlus Sunnah, categorized into two types: bid'ah sayyi'ah and bid'ah hasanah. Bid'ah sayyi'ah is any practice that are forbidden to do. While bid'ah hasanah, any practices that implied goodness is recommended to do.

The categorization of Heresy from Salafi above could trigger potential conflict in the community, many of which fell under those categories. Many religious practices in the community will be accused of heresy. For example, the Salafi criticized the practice of commemorating the prophet's birthday in the month of Rabiul Awwal, which is mostly carried out by Muslim communities in South Kalimantan, especially in Martapura and Barabai. According to them, this practice categorized as heresy, especially when the audience believed that the Prophet is present on that occasion. It can be seen from the act when the audience stands to welcome and honour the Prophet. Besides, this practice resembles with the tradition in Christian; therefore it is shirk and khurafat. Even in some of the Maulud event, the chanting of praise to the Prophet is sometimes exaggerated and contains elements of shirk.

Specifically, the establishment of Radio Gema Madinah at the Sharifah Shalihah Mosque, Martapura, has raised several religious issues, regarding the creed, fiqh, and interpretation of particular surah. Among many materials, tawheed is the primary material that often creates tension for the audience (public). In this talks, the Salafi often attack the rituals performed by other groups (traditionalist) that are considered by Salafis as heresy, such as tahlilan, grave pilgrimage, mauled, and other holidays celebration. According to Salafis, the

\footnotetext{
Penodaan Ajaran Ahlus Sunnah Wal Jamaah (Jakarta: Pustaka Imam Bonjol, 2016), 131.

${ }^{32}$ Syamsuddin, 130-131.
}

\footnotetext{
${ }^{30}$ Najib, "Gerakan Wahabi: Ajaran Dan Metode Penyebaran," 14.

${ }^{31}$ Zainal Abidin Bin Syamsuddin, Buku Putih Ahlus Sunnah Wal Jamaah: Menyingkap Penistaan Dan
} 
practice has no basis in the Qur'an nor the Hadith, nor does the Salaf generation. ${ }^{33}$

The content of the streaming lectures caused turmoil for the majority of Martapura residents who adopted the Nahdlatul Ulama (NU) understanding. As a result, the NU Martapura reported Radio Gema Madinah to the local Ulema Council and demanded to close the radio broadcast. To reduce the conflict, the management of the Sharifah Saleha mosque and Radio Gema Madinah apologized to Guru Khalilurrahman, who served as a chairman of MUI Martapura, as well as a respected figure from NU. According to Guru Khalilurrahman, the unrest arose as a result that the Salafi group did not understand the culture of the Martapura people. $^{34}$

The tension caused by the broadcast of Radio Gema Madinah affected not only the Nahdlatul Ulama (NU) but also the Muhammadiyah organization. Muhammadiyah and Salafi have similarities in the attempt of religious purification. However, there are differences between Salafis and Muhammadiyah in interpreting the Qur'an and Hadith. Salafis are more textual, totally rejecting the role of reason.. While Muhammadiyah is more contextual, trying to make sense of the spirit in the text and trying to use the power of reason. As a result, Muhammadiyah also challenged the dakwah of Salafi, Muhammadiyah event invited Salafi to have a dialogue, but the Salafi rejected and apologized instead 35

Radio Gema Madinah broadcast every day to spread Salafi propaganda to the public. The Salafis had attacked the Muhammadiyah establishment regarding the use of the Hisab method in the initial determination of Ramadan and Eid al-Fitr (1 Shawwal) because the results were often contrary to the government's decision (ulil amri). This criticism spread among communities and triggered a conflict that required the preachers of Salafi to leave
Martapura and Radio Gema Madinah to be closed. However, due to peace between the two parties (Salafi and the local government/community) through dialogue and agreement, finally, the eviction and closing of radio broadcasts did not take place.

\section{Conflict as a Result of Religious Expressions}

Conflict, according to the sociological category, contrasts with the notions of peace and harmony. The latter is the result of the associative process; while the former is the dissociative process. The associative process is a process that unites people, and dissociative is a process of separation and splitting the community. Conflict and harmony or peace as a social fact involve at least two parties (groups) of different religions. Conflict refers to the discrepant relationship between individuals and or groups, whereas peace or harmony refers to a good relationship between individuals or groups.

In religious life, frictions and conflicts between religious communities often occur due to various reasons. The reasons can be related to religious doctrine and to non-religious issues such as economic or social problems. The emotional ties between communities is diminishing as a result of differences in perspective. For examples are related on how to dress, the relationships between men and women, the neglect of the tradition of thanksgiving or baaruh which is generally a unifying events in the society.

The lack of interaction between these communities has led to certain stigma arising from the Salafi movement. One of a research informants, UWY, a former HTI activist, stated that people should be careful with the Salafi ideologies, especially the children who attended their school. He further said that Salafi people tend to think that their manhaj is the most correct, without listening to the

\footnotetext{
${ }^{33}$ Din Wahid, "Kontestasi Otoritas Agama: Radio Dakwah Di Ranah Banjar," in Suara Salafisme: Radio Dakwah Di Indonesia, ed. Din Wahid and Jamhari
}

Makruf (Jakarta: PPIM UIN Syarif Hidayatullah Jakarta, 2017), 70.

${ }^{34}$ Wahid, 70.

${ }^{35}$ Wahid, 71. 
arguments of other groups. However, he also said that the Salafi Manhaj indeed tends to be more accommodating with the surrounding community since the arrival of Raja Salman and his ministers to Indonesia. The informant also said that for studying the Qur'an, Arabic language science, Salafis are indeed the masters. He mentioned his own experience when studying Arabic in Yogyakarta is one of Salafi Boarding school.

Another informant, Iyul (58 years old) one of the followers of the Al Umm Barabai Mosque, told that despite many differences in teachings between him and her parents, especially about the celebration of the birthday of the Prophet SAW, haulan and tahlil, as a child, she felt that she is still obliged to respect his parents, a form of birrul walidain. When the events are held by the family, she still contributes to the event by taking part in providing financial support for the event with her brothers. She also helped in preparing all the needs related to the celebration. When the procession took place, she did not attend, but when the event was over, she came and socialized with friends and other family members who were also present at the event.

Iyul stated further that her husband is the adherent of Salafi. When they got married, he refused to stay in Iyul's family. Iyul's husband not only refused to participate in the celebration of commemorating the Prophet's birthday in Iyu['s family but also in his own family. The relationship between Iyul's husband and his brothers no longer harmonious.

Many people who decided to join the Salafi group caused the relationship with their family members disturbed. This disharmony related to the teaching of Salafi, which limits the relation between man and woman, the way to dress which they suggest wearing long and tight veiling some include wear chador. Family conflict usually emerged following their family member followed the Salafi.

Siti Tarwiyah reports in her article that being a Salafi woman, especially in Banjar, is not easy. Compared to other Islamic schools, becoming a Salafi requires a strong determination, mainly because she has to withdraw from the social environment, family, work, and change the way to dress. Apart from those who remain steadfast in being Salafis, most of the followers have failed. Some of the followers are given up especially when they felt that they could not agree to the Salafi moral conduct and dress code consistently. Many of these followers are university students. ${ }^{36}$

\section{From Conflict to Integration}

Conflict or dispute, especially involving humanity as history has told, can never bring peace to the relationship between individuals and groups. The implication, can not be expected to produce prosperity for humankind, other than chaos and unrest in life. Therefore a conflict does not need to be prolonged and needs to be ended or minimized.

Efforts to minimize conflict can be carried out by various parties, in this context by Salafi through their activities in South Kalimantan. Although they are mostly identified to be a source of conflict, theyhave strategies to minimize the conflict. In this case, they reduce the conflicts and tried to integrateinto society.

In the case of South Kalimantan, the Salafi made several efforts to avoid conflict and build integration among elements of the community. This effort is a strategy of Salafi to communicate more intensively with the community and to get access to it.

Some aspects of this integration strategy are: First, the issue of mosque and foundation nomenclature of the Salafi. The selection of this nomenclature is essential, because it is the first step to build communication with the surrounding community so that the people do not feel strange with the presence of this group. For example, the Salafi knew that the Muslim in Banjar honour Imam Syafi'i so that the Salafi named after Imam Syafi'i to their mosque of. In Barabai, they called the mosque after the Al Umm Mosque. While in Martapura, which is

\footnotetext{
${ }^{36}$ Tarwiyah, "Perkembangan Dan Tantangan Sosial Kehidupan Perempuan Salafi Di Kalimantan Selatan.”
} 
very familiar with the tradition of ahlul bait (habaib), the name chosen is Syarifah Shalihah Mosque.

Second, the Salafis intensively build good communication with community leaders / local officials. One of the respondent UH, the leader of Salafi in Barabai, stated that the Salafi intensively build interaction with various elements in the society. Building a good relationship with local authorities made them easy to get recommendations in building a mosque, although the conditions do not meet. For example, when they build a mosque in Banjarmasin, it was inaugurated by the Governor at that time, Rudy Arifin. This attempt is to show that their mosque is legal and approved by the local government. Another example is when there is a protest toward the Salafi by the community regarding their preaching activities in Radio Gema Madinah in Martapura; the Salafi member directly apologized to the prominent ulama, ustadz Khalil. Likewise, they apologized to the Muhammadiyah party when a response arose due to accusations of being a heresy maker for using the reckoning method in the initial determination of Ramadan and Eid.

Third, In some instances, the Salafi avoid differences with the community concerning religious practices. Ustadz UAZ, the leader of Salafi in Banjarmasin, for example, avoided discussing about local community religious practices that may trigger conflict. In the case of Martapura, the Salafi affiliated to Al Irshad an established organization, to get the acceptance from the local community While in Barabai, the Salafi figure, UH, chose to live and be active in the congregation at the community center, rather than exclusively residing in the $\mathrm{Al}$ Umm Mosque complex.

In the case of Salafi followers, a compromise effort was also established, for example, by continuing to attend Yasinan invitations. RM in Barabai stated that he participated at the call of Yasinan although he recited other surahs in the Qur'an, not just Yasin. According to Salafi, this congregation is heresy. Likewise, in the case told by AHR, an official in the Ministry of Religious Affairs in Barabai mentioned that in his village, a Salafi follower still attends handilan events and joins the congregation in langgar (small mosque).

The above description is an individual opinion of the Salafi to continue building communication with the community. However, many Salafis refused to manage good relationships with the community around them. Many of them keep a distance from their community, especially for women. The Salafi women even quit their jobs because they considered a career woman is contadict to the teachings of the Salafis. Some of them leave their families to maintain their beliefs.

Fourth, strengthen social and philanthropic aspects to the surrounding community at certain moments, such as in Eid celebrations. For example, Salafi often held fundraising to help the local community in need. Many Salafi followers belong to the upper-middle class so that this event is successfully managed. This social activity in Martapura, for example, providing consumptions for the Friday prayer attendees. Besides, the Salafi also organized social services such as mass circumcision, distribution of sacrificial meat on the day of the Sacrifice to the community, and others. This form of action is very supportive of the dissemination of the cultivation of Salafi values in the community. In Barabai, according to Ustadz $\mathrm{H}$, they gave Eid packages to the pedicab drivers and provided 1000 qurban meat packages. This activity is held regularly to build a good relationship with the community.

Fifth, the Salafi emphasize in their preaching activities to return to the primary source of Islamic teachings, the Qur'an, and learn religious teachings directly from the source. In their preaching, the Salafi provide arguments taken from the primary source of Islam that made the audience satisfied and join the group. Many of Salafi followers refer to this reason when they enter the group. Another aspect is they build a center for memorizing the Qur'an for children (tahfidz Qur'an). This educational institution specializes in strengthening tahfidz ability and became the 
main attraction for some people to lodge their children into these Salafi schools.

The existence of Radio Gema Madinah and Rodja TV broadcasts, as well as various other information technology such as WhatsApp, Facebook, Twitter, Instagram, become essential vehicles for Salafi to continue building communication with various parties to introduce Salafi-Wahabi teachings closer to Public. They are continuously spreading their teachings of Salafi so that known by the community, and hopefully, many will join them.

\section{CONCLUSION}

The notion of a Salafi-Wahabi purification, which is prone to cause conflict with others, is related to two aspects: material and formal. In the material element, it is associated with the content or material of the teachings developed by Salafi-Wahabis in general, namely the idea of monotheism (tawheed) and following the sunnah of the prophet. Of the three types of monotheism taught in the Salafi-Wahabi understanding, the tawheed uluhiyyah and the tawheed asma wa shifat, and tawheed rububiyyah. In tawheed uluhiyyah, giving birth to the concept of shirk directed towards those who are considered impure in worshiping God. Whereas in the aspect of asma and sifat, the idea gave rise to tajassum or mujassimah. The concept of itba 'sunnah has given birth to the idea of heresy, many of which accusations addressed to the traditionalists (NU), who are seen as doing many impure practices. In the formal aspect, which relates to purification strategies, the use of public media such as radio and TV and social media, is seen as contributing to the emergence of conflict in society. The existence of Gema Madinah radio, in particular, has made it possible for the teachings of the purification of Salafi-Wahabi Islam to enter a space that is not only listened to by ideological circles but also from different groups. Their calling to return to the pure teachings of Islam often triggered conflict among the community.

There are several integration models carried out by the Salafi-Wahabi group in South
Kalimantan. They are as follow: 1) the establishment of the Mosque and the Foundation owned by the Salaf-Wahabi; 2) the Communication (gathering) involving community leaders / local officials; 3) accommodating with local culture; 4) Avoiding sharp differences in religious practices related to Shirk and Bid'ah; 5) strengthen social and philanthropic aspects to the surrounding community; 6) the call to return to the source of Islamic teachings, the Qur'an.

\section{REFERENCES}

Abidin, Muhammad Zainal. "Ulama in Indonesian Urban Society: A View of Their Role and Position in the Change of Age." Jurnal THEOLOGIA 28, no. 2 (2018): 235. Administrator. "Sejarah Awal Muhammadiyah Di Kalimantan Selatan." PW Muhammadiyah Kalsel. Accessed October 13 , 2019. http://kalsel.muhammadiyah.or.id/content3-sdet-sejarah.html.

Arianti, Anita. "Gerakan Pemurnian Islam Syekh Muhammad Arsyad Al-Banjari Di Kalimantan Selatan." Al-Fikr 14, no. 3 (2017): 377-90.

Faizah, Faizah. "Pergulatan Teologi Salafi Dalam Mainstream Keberagamaan Masyarakat Sasak." Ulumuna 16, no. 2 (November 7, 2017): 375-402. https://doi.org/10.20414/ujis.v16i2.183.

Fuad, A Jauhar. "Infiltrasi Salafi Wahabi Pada Buku Teks Di Madrasah Dan Respons Warga Nahdliyin." Marâji: Jurnal Ilmu Keislaman 1, no. 2 (2015): 361-92.

Hakami, Syaikh Hafizh bin Ahmad al. Akidah Golongan Selamat. Translated by Amin Ulwi. Jakarta: Pustaka Imam Bonjol, 2015.

Hasan, N. "The Salafi Movement in Indonesia: Transnational Dynamics and Local Development." Comparative Studies of South Asia, Africa and the Middle East 27, no. 1 (January 1, 2007): 83-94. https://doi.org/10.1215/1089201x-2006045.

Ibrahim, Abadir M. "Localizing Salafism: 
Conflict and Integration in The Salafi-Wahabi

Religious Change among Oromo Muslims in Bale, Ethiopia." African Studies Quarterly 16, no. 2 (2016): 127-28.

Jinan, Mutohharun. "Dilema Gerakan Pemurnian Islam." Ishraqi 4, no. 1 (2008): 57-72.

Mujiburrahman. "Islamic Theological Texts and Contexts in Banjarese Society: An Overview of the Existing Studies." Southeast Asian Studies 3, no. 3 (2014): 611-641.

Najib, Agus Moh. "Gerakan Wahabi: Ajaran Dan Metode Penyebaran." In Gerakan Wahabi Di Indonesia (Dialog Dan Kritik, edited by Yudian Wahyudi. Yogyakarta: Bina Harfa, 2009.

Noer, Deliar. Gerakan Moderen Islam Di Indonesia 1900-1942. Jakarta: LP3ES, 1996.

Qodim, Husnul. "Dinamika Salafisme Di Indonesia: Akar-Akar Intelektualitas Dan Orientasi Ideologis Yang Beragam." Tashwirul Afkar: Jurnal Refleksi Pemikiran Keagamaan Dan Kebudayaan, no. 21 (2007): 46-74.

Rahmadi, Rahmadi. "Pembaharuan Islam Di Kalimantan Selatan Awal Abad Ke-20." AlBanjari: Jurnal Ilmiah Ilmu-Ilmu Keislaman 13, no. 1 (May 12, 2014). https://doi.org/10.18592/albanjari.v13i1.390.

Ramadhani, 'Abdul Malik. 6 Landasan Utama Dakwah Salafiyyah. Translated by Mubarak Bamuallim. Jakarta: Pustaka Imam Syafii,
2015.

Syahbana, Takdir Ali. "Fenomena Salafi Di Kalimantan Selatan." Jurnal Ilmiah Ilmu Ushuluddin 14, no. 1 (2016): 67-82.

Syamsuddin, Zainal Abidin Bin. Buku Putih Ahlus Sunnah Wal Jamaah: Menyingkap Penistaan Dan Penodaan Ajaran Ahlus Sunnah Wal Jamaah. Jakarta: Pustaka Imam Bonjol, 2016.

Tarwiyah, Siti. "Perkembangan Dan Tantangan Sosial Kehidupan Perempuan Salafi Di Kalimantan Selatan." Jurnal Lektur Keagamaan 15, no. 2 (December 30, 2017): 470. https://doi.org/10.31291/jlk.v15i2.533.

Wahid, Din. "Challenging Religious Authority: The Emergence of Salafi Ustadhs in Indonesia." Journal of Indonesian Islam 6, no. 2 (December 1, 2012): 245-64. https://doi.org/10.15642/JIIS.2012.6.2.245264.

. "Kontestasi Otoritas Agama: Radio Dakwah Di Ranah Banjar." In Suara Salafisme: Radio Dakwah Di Indonesia, edited by Din Wahid and Jamhari Makruf. Jakarta: PPIM UIN Syarif Hidayatullah Jakarta, 2017.

_. "Nurturing Salafi Manhaj A Study of Salafi Pesantrens in Contemporary Indonesia." Wacana 15, no. 2 (2015): 36776.

Zainu, Syaikh Muhammad Bin Jamil. Jalan Golongan Yang Selamat. Translated by Ainul Haris Umar Arifin. Jakarta: Darul Haq, 2016. 